\title{
DELIVERING ISLAMIC STUDIES AND TEACHING DIVERSITY IN SOUTHERN THAI ISLAMIC SCHOOLS
}

\author{
Raihani*; Promadi Karim**; Sopyan M. Asyari***; Nunu \\ Mahnun**** \\ $*, * *, * * *, * * * *$ Sultan Syarif Kasim State Islamic University (UIN) \\ Riau, Indonesia \\ email:r41b4n1@gmail.com
}

\section{Abstract}

Teaching religious and cultural diversities would possibly be one of the greatest challenges to teachers of Islamic in Southern Thai Islamic schools due to the strong Islamic ideology they hold, lack of proper training for their professional growth, and the ongoing ethno-political conflict in the area. This paper explores how such a challenge has been faced. It particularly describes the teaching process of Islamic studies in Thai Islamic schools and explores opportunities within it for promoting religious and cultural diversities. We also look into possible opportunities for Islamic teachers to teach and students to learn about the diverse reality of society. We found that the deliveries of Islamic fell squarely within the concept of teaching into religion using a heavy confessional approach. Indoctrination with a little encouragement of critical thinking was common in Islamic classes. The presentation of other faiths and cultures was designed to explore their weaknesses and fallacies from a single believed-Islamic perspective.

[Pengajaran keragaman budaya dan agama merupakan sebuah tantangan besar bagi guru pendidikan keislaman pada sekolah di Thailand Selatan, seiring dengan pemahaman keislaman mereka yang kuat, kesenjangan tingkat perkembangan profesionalitas, dan konflik politik etnik di daerah tersebut. Tulisan ini mengetengabkan persoalan yang mereka hadapi, kbususnya 
Raihani, et al.

deskripsi proses pengajaran studi keislaman di sekolah Islam lokal dan peluang dalam promosi keragaman budaya dan agama. Tulisan ini juga melihat kemungkinan peluang bagi guru agama Islam dan anak didiknya untuke saling belajar dari realitas keragaman dalam masyarakat. Kami menemukan bahwa menyampaikan pengetahuan keislaman harus tepat dengan konseppengajaran bagipemeluk agamanya menggunakan pendekatan keyakinan yang lurus. Indoktrinasi dengan sedikit dorongan pemikiran kritis merupakan kewajaran dalam kelas agama. Presentasi agama dan budaya lain didesain untuk eksplorasi kekurangan dan kesalahan dari perspektif yang monolitik.]

Keywords: Islamic education; Islamic studies, Southern Thailand conflict; religious diversity

\section{A. Introduction}

It is undoubted that religious education influences the way people shape their worldview including perception of other people of different religions and cultures. It plays an important role in enabling students to view differences positively or otherwise. This role is played in various forms including the school's curriculum orientation and content, teacher's belief and experiences, instructional approaches, and culture and milieu. Covering these aspects of schooling, Grimmit divides religious teaching into three models, namely: teaching into religion, teaching about religion, and teaching from religion. ${ }^{1}$

Teaching into religion, which is also described as the confessional approach to religious teaching, is where a single tradition is taught as the religious education curriculum by insiders. The main objective of this approach is to transmit or nurture the faith and the teachings of a particular religion, and to implant commitment of students to it. Correspondingly, this approach is largely in favor of the use of indoctrination to teach religious dogmas, which entails the aim to close the minds of the students to other options in an uncritical manner. Tan argues that the confessional approach failed to convince the liberalists' concerns

${ }^{1}$ Michael Grimmitt, Religious Education and Human Development: The Relationship between Studying Religions and Personal, Social and Moral Education (Great Wakering, Essex: McCrimmon, 1987), p. 255. 
of the rational autonomy that should be developed in students, but is absent in such an approach. ${ }^{2}$ Jackson explains that in the secular country contexts confessional approach is usually endorsed by the community as opposed to the state that is in favor of more open approaches to religious education. ${ }^{3}$

Teaching about religion refers to the religious studies approach, which involves learning about beliefs, values and practices of the world religions. There is no intention to nurture faith in the learners, but students are given opportunities to learn about religions in a neutral and objective fashion. This approach gains a strong support from secular and liberal societies that put high respect to openness, objectivity, and neutrality. Meanwhile, teaching from religion gives students an opportunity to consider different responses to major religious and moral issues, so that they may develop their own views in a reflective way. This approach outs the students' experiences at the center of the learning process, and engage two types of evaluation, namely impersonal evaluation and personal evaluation. Grimmitexplains that impersonal evaluation is to apply critical judgments about religion and about truth claims, beliefs and practices of religion(s). Personal evaluation refers to the making of critical judgments about own religious beliefs and values, a process of self-evaluation. ${ }^{4}$

Despite the high consideration and wide practices of the learning about and from religion models particularly in secular contexts, their applicability in a strong religious country might attract disagreements. The demand of the community for religious education that enables children to become religious individuals is strongly influential in the way religious education is developed and enacted. Although the last two models do not necessarily neglect the truth claim of every religion

2 Charlene Tan, "Christian Education Without the Problem of Indoctrination", Quodlibet Journal, vol. 5, no. 4 (2003), pp. 1-5.

3 Robert Jackson, "Intercultural Education, Religious Plurality and Teaching for Tolerance", in Intercultural Education and Religious Plurality, ed. by Robert Jackson and Ursula McKenna (Oslo: The Oslo Coalition on Freedom of Religion or Belief, 2005), pp. 5-13; Robert Jackson, "Tolerance in Religious and Citizenship Education: Interpretive and Dialogical Approaches", presented at the Teaching for Tolerance in the Indonesian Context (Makassar, 2007), p. 6.

${ }^{4}$ Grimmitt, Religious Education and Human Development, pp. 225-6. 
Raihani, et al.

studied, the avoidance of it is essentially against the very objective of the confessional model of religious education, which is to produce religiously committed individuals. In this way, Kalve criticizes the secular humanist perspective underpinning the models, and claims that they would not be well accepted by most parents who want to see their children to develop on and within their own tradition. ${ }^{5}$ Therefore, there should be a middle way between the confessional and the more neutral models to cater such an interest for pious individuals and the other for respectful and tolerant ones. In other words, a religious education approach should facilitate to the creation of religious multicultural and tolerant individuals.

This paper describes the teaching process of Islamic studies in Thai Islamic schools and explores opportunities within it for promoting religious and cultural diversity. By Islamic studies we mean subjects that teach about Islamic knowledge including Islamic faith, Islamic ethics, Islamic laws, al-Quran, the Prophetic traditions and the like as specified in the schools' curriculum. Within the subjects, we look into possible opportunities for teachers to teach and students to learn about the diverse reality of society. Although this theme would possibly be a greatest challenge to Islamic studies teachers, ${ }^{6}$ such opportunities may be found in the curriculum content, textbooks and the process of classroom implementation. This investigation was conducted in three Islamic schools in the Southern Thailand; the description of each will be conveyed later in this paper. The main reason to choose Southern Thai Islamic schools is the complex situation of the area which has been exposed to an ongoing conflict between Malay Muslim fighters and Thai government army. In other words, it is important to see how Islamic religious teachings and religious and cultural tolerance are developed and implemented in the schools in the conflict area, and how these can be improved to help the promotion of peaceful coexistence in community. By religious tolerance, we are not in any way to say that the deep South conflict has been religious, but since the two conflicting sides come from different religious backgrounds, religious sentiments cannot be entirely

5 Peter Kalve, "Some Aspects of the Work of Michael Grimmitt", British Journal of Religious Education, vol. 18, no. 3 (1996), pp. 181-90.

6 Joseph Chinyong Liow, Islam, Education, and Reform in Southern Thailand: Tradition \& Transformation (Singapore: Institute of Southeast Asian Studies, 2009), p. 2. 
peeled off from the problem. So, part of the investigation is to see how religious tolerance was taught in the schools.

The Southern Thai conflict can be traced back to the history of the annexation of the Pattani Malay Islamic kingdom by the Thai kingdom in 1906. Liow describes that the annexation of Pattani Darussalam and six other sultanates was done first by conquest and then by diplomatic moves into Siam. Malay Muslims in the southernmost have resisted through continuous, but tending to be sporadic, armed struggles. ${ }^{7} \mathrm{~A}$ series of exchanged attacks by the insurgents and the government have occurred since 1960s and claimed thousands of dead and more injuries. Bombs have blasted terrorising people indifferently, and the government military operations have created further fear. ${ }^{8}$ On 28 April 2004, Muslim militants launched more largely organised attacks on the government army positions in the three provinces of Yala, Pattani and Narathiwat and claimed a big number of casualties from both the insurgents and the government apparatus. The 2004 attacks by the militants manifested an ostensible goal of the insurgency that wanted the area to be an independent Malay-Muslim state within five years since January, 2004. ${ }^{9}$ This objective was surely not achieved, but left the southernmost area until now to have been unstable as officially acknowledged by the government. In essence, the situation in Southern provinces of Pattani, Narathiwat and Yala remains bad and hard to control.

The Muslim community in the deep South has faced and still faces physical threats to its existence. ${ }^{10}$

${ }^{7}$ Joseph Chinyong Liow, Muslim Resistance in Southern Thailand and Southern Philippines: Religion, Ideology, and Politics (Washington, D.C.: East-West Center, 2006), pp. 24-5.

8 Joseph Chinyong Liow, "International Jihad and Muslim Radicalism in Thailand?: Toward an Alternative Interpretation", Asia Policy, vol. 2, no. 1 (2006), pp. 89-108.

9 Peter Chalk, The Malay-Muslim Insurgency in Southern Thailand -- Understanding the Conflict's Evolving Dynamic, Occasional Papers, no. 5 (Santa Monica, CA: RAND Corporation, 2008); Don Pathan and Joseph Chinyong Liow, Confronting Ghosts: Thailand's Shapeless Southern Insurgency, no. 30 (Lowy Institute for International Policy, 2010), pp. $70-1$.

10 Otto Von Feigenblatt, "The Muslim Malay Community in Southern Thailand: A 'Small People' Facing Existential Uncertainty”, Ritsumeikan Journal of Asia Pacific Studies, vol. 27 (2010), p. 60. 
Raihani, et al.

In this paper, we will briefly describe the development of Islamic schools in the Southern Thailand and their engagement with such an ongoing insurgency. We will highlight the Thai government's strategies on Islamic education in order to persuade Malay Muslims in the area. Following this, we will explain our chosen approach and methods of investigation which stresses on the importance of narratives in depicting the phenomena being studied. Finally, we will describe the findings in a critical way through considering both historical and contextual perspectives of the Islamic schools.

This study used a social anthropology approach ${ }^{11}$ focusing on examining how and why cultural diversity is contained in the curriculum of Islamic studies and taught to students. This study approached the teaching of cultural diversity as a unique phenomenon that requires comprehensive and in-depth investigation, which cannot be fully uncovered through a numerically quantitative approach. Cultural diversity is a situation where different religions, cultures, values, norms, traditions and so forth live co-existentially in one place and one time. ${ }^{12}$ People who live in this situation are exposed to experience this cultural diversity and learn to understand, perceive, and act upon it based on perspectives they have developed. In school, this living experience, developed and wrapped in a more academic form, is contained and presented in curriculum and then taught to students. This new form requires conceptualisation, understanding, clarification, internalisation, transfer and teaching from teachers to students and is bounded in certain social, cultural and political contexts. To unravel this complex phenomenon is to study it in-depth using a qualitative approach.

\section{B. Islamic Schools in Southern Thailand}

The politics of education in the Southern Thailand provinces of Pattani, Narathiwat and Yala more or less resembles the existing

11 Matthew B. Miles and A.M. Huberman, Qualitative Data Analysis: an Expanded Sourcebook (Thousand Oaks: Sage Publications, 1994).

12 James A. Banks, Cultural Diversity and Education: Foundations, Curriculum, and Teaching, 5th edition (Boston: Pearson Education, 2006); David Corson, Changing Education for Diversity (Buckingham: Open University Press, 1998); Tracy Taylor and Kristine Toohey, "Negotiating Cultural Diversity for Women in Sport: From Assimilation to Multiculturalism", Race Ethnicity and Education, vol. 1, no. 1 (2006), pp. 75-90. 
conflict between the government and Malay Muslims. In every context, education is always used as a battlefield of contesting ideologies and political interests between different groups of people - be religious or political. This section will describe briefly history of the Islamic education in Southern Thailand and, particularly, the efforts by the government to influence such a system.

Education in the Southern Thailand provinces has been characterized heavily by the presence of pondok, parable to pesantren in Indonesia and pondok in Malaysia, which teaches Islamic knowledge and places a Tok Guru (school grand teacher) as a central figure in the system. ${ }^{13}$ Pondok implements a traditional approach to Islamic teaching using oldfashioned methods of instructions i.e., kitab-based and lecturing. Usually, the curriculum is designed following the established levels of books within the Shäfí madhbab. In learning circles (balaqah), teachers usually read some paragraphs and explain whilst pupils jot down what seem important to them. This circle incorporates a few questions and answers.

Generally, Thai Buddhists regard the pondoks in the South as hotbeds of Muslim radicalism and political activism. ${ }^{14}$ This does not go without reasons. There was a document leak from Thai military that noted at least 50 educational establishments spread throughout the three provinces of Pattani, Yala, and Narathiwat where Muslim militants came to recruit and train students for holy war. ${ }^{15}$ Because of this, Thai government has tried to control its system through several approaches and policies. Madmarn ${ }^{16}$ explains that there was an explicit intention by the government to exert Thai influence on the educational system and process in Malay Islamic community. The government has employed an approach to infuse government curriculum into the pondok system, from which some of the pondoks transformed into madrasah or Islamic schools. As a result, these private Islamic schools teach both academic

13 Liow, Islam, Education, and Reform in Southern Thailand, pp. 30-3; Hasan Madmarn, The Pondok \& Madrasah in Patani (Selangor: UKM Press, 1999), p. 23.

${ }^{14}$ Sarkar Diptendu, "Religious Minority, Education and Separatism in South Thailand", Thailand in the World. (Sydney: University of Sydney, 2014), p. 14.

15 Anthony Davis, "Thailand Confronts Separatist Violence in Its Muslim South”, IHS Jane's Intelligence Review (2004), p. 13.

16 Hasan Madmarn, The Pondok \& Madrasah in Patani, p. 72. 
Raihani, et al.

curriculum and Islamic curriculum. Another approach that was used to be implemented by Thai government was to impose the use of Thai language in Islamic education system with the intention to take over Arabic and Malay languages from the schools and, in turn, from Muslim community at large. Arabic and Malay are both significant identity for Malay Muslims in that area. This policy, however, had been far from successful mainly because the Malay language particularly was regarded as part of ethnic identity of Muslims in the area. Madmarn describes:

Through introducing Thai education into the Islamic school, the government hopes that the Thai language will take over from the Arabic as well from the Malay languages and there after replace them in their daily lives. The Malay has not faded away as the government might have hoped. ${ }^{17}$

Since 2006 Thai government has issued the Education Development Plan of the Provinces along the Southern Border promoting massive and remarkable reforms on education in the south. ${ }^{18}$ One of the aspects to reform is that the use of dual languages - Thai and Malay - in schools has become a mandate. Other initiatives include the improvements in teacher training, school facilities, career development for school graduates, and higher education. With such an enormous support from the government, the transformation of pondoks into private Islamic schools has been increasing with the purpose of enhancing efficiency and quality, ${ }^{19}$ even though some remain reluctant to accept the change because of their concern with maintaining Islamic traditions and identity through such traditional Islamic education.

Despite the change imposed to local communities in the Muslim majority provinces, the Thai government still maintains its strict control over the schools' curriculum by establishing the Office of Private Education under the National Education Act (2542/19999). The Office works closely with individual Islamic schools and school associations to coordinate the curriculum at elementary (ibtidā $)$, middle (mutawassit), and secondary (thänawr) levels. The curriculum itself is divided relatively

17 Ibid., p. 73.

18 Liow, Islam, Education, and Reform in Southern Thailand, pp. 30-3.

19 Khanittha Saleemad, Suwattana Eamoraphan, and Watana Vinitwatanakhun, "Development of a Leadership Model for Islamic School Leaders in Thailand", Scholar, vol. 4, no. 2 (2012), pp. 68-72. 
evenly between religious and general subjects (50-50), even though certain schools have instituted a breakdown consisting of 18-22 hours per week for religious education and 22-28 hours a week for secular subjects. The effect of this policy, however, has been the increasing move by Muslim parents in the area to remove their children from government schools as they view the government schools only take Muslim children off their Malay Islamic values..$^{20}$ As a result, majority of Muslim students, estimated around $85 \%$, in the south attended private Islamic schools. ${ }^{21}$

\section{Curriculum Content and Orientation}

This section onwards describes relevant findings of the research incorporating critical analysis of the data. We present findings based on themes across the three Islamic schools developed deliberately to cater the purpose of this paper.

There are generally eight different subjects that fall under Islamic studies in each of the three Islamic schools. The list of the subjects includes al-Quran and its Exegesis (Tafsir), the Prophetic traditions (alHadith), Islamic Faith ('Aqidah), Islamic Jurisprudence (Fiqh), Islamic History (Tärikh), Islamic Ethics (Akbläq), the Arabic and Malay languages. These subjects were approved by the association, but there were variations in terms of the enacted Islamic curricula across the three madrasah. For example, Logics (Mantiq) is added in the Narathiwat's curriculum. Also there was a great variation across the three schools in terms of the scope and depth of each subject. The Yala's Islamic school principal said that there was an agreement made through the board of Islamic schools regarding such Islamic subjects, but every school had its own liberty to adopt and adapt the contents to its context. This variation indicates the autonomy of each Islamic school in Southern Thailand to determine their curriculum, its orientation, and contents. The board of private schools as previously mentioned served only as a coordinating and bridging body amongst schools, and between schools and the government.

The autonomy of the Islamic schools cannot be divorced by the

${ }^{20}$ Melanie Carol Brooks and Ekkarin Sungtong, "We still have bombings': school principals and insurgent violence in Southern Thailand", International Journal of Leadership in Education, vol. 19, no. 5 (2016), pp. 1-30.

21 Liow, Islam, Education, and Reform in Southern Thailand, p. 41. 
Raihani, et al.

fact that historically, as explained before, they were developed as pondoks that taught only Islamic subjects in traditional ways. The move to adopt modern curriculum designed by the government was considered as a breakthrough to reform the curriculum given the ongoing conflict between Malay Muslims and the government. Some other pondoks, as the Pattani's Islamic school principal explained, did not want to change to incorporate the government-imposed curriculum because of the suspicion of the government tricks to hijack Islamic education for its political purposes in the deep South. From a positive political point of view as conveyed by the principals and teachers in the three schools, however, the integration of the two curricula (perhaps, we would consider "juxtaposition") can be seen as a manifest of both Muslims and the government to compromise and accept each other. Furthermore, from a more pragmatic view, the needs of Malay Muslim youths for both knowledges -Islamic and saman- have been increasingly stronger given the global and social changes, and the adoption of modern curricula has been considered the answer. The Narathiwat's Islamic school vice principal argued:

We are in the era of ASEAN economic community. Our students need to be able to survive this global competition. ${ }^{22}$

Like pesantren in Indonesia, the contestation and marriage between traditionalism and modernism ${ }^{23}$ occurred in these three Islamic schools where the competing ideologies and interests are manifested in the school curriculum and rituals. Yet, the ideal aspiration of all the Islamic schools is generally oriented to the development of Islamic personality of students who master not only Islamic subjects but also saman ones in order for them to live successfully in this world and the hereafter. ${ }^{24}$

The above curriculum paradigm was written in the visions of each studied Islamic school. Narathiwat's school was envisioned to provide

22 Interview with the Vice Principal of Narathiwat's Islamic School, 5 Sep 2015.

${ }^{23}$ Ronald A. Lukens-Bull, "Two Sides of the Same Coin: Modernity and Tradition in Islamic Education in Indonesia", Anthropology \& Education Quarterly, vol. 32, no. 3 (2001), pp. 350-72. Indonesia, seeks to negotiate modernization and globalization through the interface of an Islamic boarding school (pesantren).

24 Profile of the respective schools (2015). This is by intention not included in the reference list to avoid possible identification of each of the schools. 
religious education to Muslims who will defend the sanctity of Islam, preach for it, eradicate false ideologies and promote social welfare and services. ${ }^{25}$ To achieve these, the school wanted to equip students not only religious knowledge but also secular sciences so that the graduates could contribute to the society at large. Pattani's Islamic school articulated its vision into becoming an institution that organizes learning in accordance with both the state's and Islamic educational standards in order to transform students into noble human beings who have the ability to speak foreign languages and master sciences. ${ }^{26}$ There is a clear and explicit emphasis on the mastery of foreign languages especially Arabic and English and sciences. Differently, Yala's school was aspired to develop strong faith in students, equip them with modern education and technology, cultivate their good health, promote green environment, and advance to the international arena (principal's interview). ${ }^{27}$ These are three different visions of three different Islamic schools, but there is one paradigm that students need not only Islamic knowledge, but also secular sciences to survive this era of globalization. This paradigm suggests an openness of the Islamic schools to modernization, which always entails competing influences from both bodies of knowledge or disciplines during the process. Yet, there was a clear message from the principals, teachers and students that Islamic religion should be the guiding principles to measure whether new sciences are valid or not, even though it was not clear as to what actions the schools would take if one of the saman subjects or content was against the understood Islamic teachings.

The presence of religious and cultural diversity in the curricula of Islamic studies is one of the emphasis of this research. Our analysis of the curriculum documents and interviews with the principals and teachers suggest that religious and cultural diversity were not explicitly and systematically contained in the curriculum. Only sporadic insertion of the topics was found in some of the subjects, and this depended largely on teachers' faith and experiences. But, from reading all these sporadic information, there seemed to be a general guideline about other religions and cultures and how to interact with the people, namely: whatever - be

\footnotetext{
25 Ibid

${ }^{26}$ Self-Assessment Report, 2015, of the Pattani’s Islamic school.

27 Interview with the Principal Yala's Islamic school,19 Sep 2015.
} 
Raihani, et al.

belief or culture - against the (understood) Islamic teachings is deemed incorrect. Students were reminded to use precautions in dealing with people of such incorrect faith and culture. Another general guideline was that differences existing in society should be seen as a playing field for spreading Islam.

Some examples of how religious and cultural diversity were contained in the Islamic studies can be mentioned here. In the subject of Quranic Exegesis, Zuhdi, a teacher in Pattani's Islamic school, explained:

Of course, there is some aspects of cultural diversity in the subject. Allah has created us differently and each of us possesses unique characters and culture. We have to respect other and should not disparage other. As Allah said: "We have created you as men and women, and We have created you in different tribes and nations, so you have to know each other". So, as a Muslim, we should respect and interact with those wo are different from us. We have Malays and Thais, and we speak Thai - the language of Buddhists. No problem! ${ }^{28}$

In our analysis of the Exegesis textbook, we did not find a dedicated topic on religious and cultural diversity, but this issue was "touched" when such a verse was presented during the lessons. In the above quote, the teacher firmly suggested that differences are something to accept, and one only way to deal with it is to respect it. As he continued, this Quranic teaching was supported by one of the Prophetic sayings that Arab is no better than non-Arab and vice versa except those who are pious.

Another example we provide here is the case of Islamic faith ('Aqidab) textbook in Narathiwat's Islamic school. This book was designed for Year 2 students of the secondary (Thänawi) level. From page 41 onwards, the book contained lessons of other religions and isms including Christianity, Secularism, Jews, and so forth. These topics were categorized into one big theme "Religions Other than Islam". Every topic was structured into a simple introduction to each of the religions or isms with particular emphasis on uncovering its weaknesses and faults. The main sources of this book in presenting other religions were Islamic texts including al-Quran. So, we cannot expect fair judgement and presentations of such religions and isms, as we understand that the objective of such one-sided comparative religious teaching is to remind

${ }^{28}$ Interview with Zuhdi, a quranic exegesis teacher,15 Sep 2015. 
students of the danger of other faiths. The textbook was written in Arabic, and we translated some of the texts as follows:

The origin of Jews, before its teachings were manipulated, was a religion from Allah which was sent down to Moses. Torat is its Holy Book. But, now it is an invalid religion because Jewish changed its teachings and Islam has abrogated it. ${ }^{29}$

The type of religion classes as described above can be categorised into confessional approach or teaching into religion, ${ }^{30}$ the objective of which is to nurture faith and commitment in students to the taught religion. There is no room for students to ponder and apply critical thinking of the dogmas presented by the teachers. When it comes to the presentation of other religions, the intention is to uncover the weaknesses and demonstrate superiority of the taught religion and faith. This strategy of teaching religion might not contribute to the education for tolerance and religious diversity as it would develop a feeling of hatred and prejudice. It would be difficult to convey different messages to students - one is to respect differences like what Pattani's principal said, whilst the other is to degrade the dignity of other religions. Therefore, as we argue previously, what should be emphasised is a humanist confessional approach. What we mean by this is that there is no wrong with confessional approach to teaching religion, but there should be an orientation to respect differences including other religions and other human beings regardless of their backgrounds. In other words, being a pious Muslim requires being respectful towards differences.

The humanist confessional approach should also be applied in terms of intra-religious diversity. As previously mentioned, during the interviews, however, we found that most informants were concerned with the recently rapid development of Wahhabism in the areas and viewed this trend as a threat to the traditional perspectives of Islamic teachings. ${ }^{31}$

${ }^{29}$ The textbook of 'Aqīidah entitled al-Aqidah al-Islämiyah li'-Marḥalah al-Thāniyah written by a teacher of the Islamic school, p.56.

${ }^{30}$ Grimmitt, Religious Education and Human Development, p. 225.

31 Interview with various informants including the Vice Principal of Narathiwat's Islamic school on 5 Sep 2015 and the Principal of Yala's islamic school, 19 Sep 2015. 
Raihani, et al.

This phenomenon is not isolated, but spread in almost all Muslim worlds, ${ }^{32}$ and has created segregation amongst Muslims. The heavy confessional approach and accusing others for going astray and making innovations (bid'ah) are the main characteristics of this group, and attracted fierce responses from other groups.

\section{Pedagogy of Islamic Education}

Pedagogy is simply the art of educating and teaching students. Pedagogy in Islamic education should follow its nature in which knowledge and values are inseparable. ${ }^{33}$ To fit this nature, holistic pedagogy does not restrict teaching practices in classroom only, but extend it into outside classroom particularly in the context of the studied Islamic schools where school cultures and values are embedded in the teaching process. This part of the article, therefore, presents pedagogy of Islamic education to include both classroom and non-classroom practices.

\section{Teaching Strategies}

Teaching strategies for Islamic studies were found to be generally traditionally monotonous. Classroom observations we conducted reveal that the teachers generally read paragraph by paragraph and explained the meaning to students, and with only a few questions and answers. This textbook-oriented lecture provided only a small opportunity for students actively interact with their peers and teachers during the class. It inhibited the application of critical thinking by students of the learnt materials and stifled their autonomy as individuals. So, this teaching strategy did not seem to be compatible with the nature of cultural diversity which surfaces the distinct uniqueness of individuals and promotes mutual acknowledgement and respect.

As acknowledged by the principals and teachers in three Islamic schools, most Islamic studies subjects used a one-way teaching strategy.

${ }^{32}$ Natana J. DeLong-Bas, Wabhabi Islam: From Revival and Reform to Global Jihad (Oxford: Oxford University Press, 2004); Noorhaidi Hasan, "The Salafi Madrasas in Indonesia", in The Madrasa in Asia: Political Activism and Transnational Linkages, ed. by Farish A. Noor, Yoginder Sikand, and Martin van Bruinessen (Amsterdam: Amsterdam Univ. Press, 2008), pp. 247-74.

${ }^{33}$ J. Mark Halstead, "An Islamic Concept of Education", Comparative Education, vol. 40, no. 4 (2004), pp. 517-29. 
For example, Yusni admitted:

I never ask students to discuss in the class [of 'aqidab]. What I want is that they do their task. For example, they have to find a topic related to 'aqidah of $A s h^{\prime}$ ari, so they discuss with their friends, read another book, find who $A s h^{\prime}$ 'ar is, where he is from, and what his opinion is. ${ }^{34}$

The above explained situation was a consequence of at least two factors, namely historical development of the madrasah and the submissive approach to religion classes. As discussed earlier, the three madrasah were originally pondok institutions that taught religion only to students. Teachers of this pondok generally came from the same institutions or other traditional schools which taught only the contents of Islam. Many of these did not have teaching strategies reformed and refined. They were never sent to teaching training or seminars. Therefore, we saw that there was a huge difference between teaching strategies of most Islamic studies teachers and those of academic teachers. The latter usually graduated from modern universities. The confessional approach has resulted in monotonous teaching strategies because critical thinking was prohibited in this approach. This is submissive, in a sense that students were asked to accept the truths that the teachers presented. So, variations in teaching strategies were rarely seen.

\section{School Cultures and Values}

Although the formal curriculum of Islamic studies and its teaching strategies suggested a little about educating and teaching for religious and cultural diversity, many activities the three Islamic schools conducted were quite promising in creating tolerant and multicultural cultures. These activities should be seen as part of teaching-learning processes. There was a range of programs developed such as the dormitory living for many students to create social cohesion, Islamic extra-curriculum which encourages mixing of different ethnic backgrounds, social internship, and collaborative curriculum development between teachers of Islamic and saman curricula. All of these activities served as a vehicle for the schools' community to develop more communal and cohesive cultures which respect diversity and differences. In Pattani's Islamic school, for

${ }^{34}$ Interview with Yusni, a teacher in Yala's islamic school, 20 Sep 2015.. 
Raihani, et al.

example, there was a sporting event which served as a venue for cross religious and cultural interactions. A teacher, Wamdi, explained:

In this school, there is Sukan Jaya "Sport" [lit. Sporting Week] in which teachers and students are involved. Muslim teachers and non-Muslim teachers are alike. This event can strengthen the relationship amongst us. ${ }^{35}$

Similar event was held regularly in Yala's Islamic school, called Family Day preceded by Sporting Week, to establish cohesive relationship among the members of the school community.

The openness towards the new (government) curriculum can be seen as a strong indication that the three Islamic schools demonstrated the willingness to compromise their traditional Islamic education system and standards. New saman subjects embedding secular ideology and paradigm were unavoidably taught to students, which might create tension and confusion among teachers and students. New teachers who mostly come from non-Islamic, mostly Thai Buddhist, background were a fact that Muslim teachers and students needed to interact with on daily basis. On one hand, the presence of non-Muslim teachers provided an opportunity for other teachers and students to interact and exposed to other faiths and cultures. They developed mutual respects, and there was no conflict reported that happened in the schools, even though outside the schools the military and insurgent activities which often targeted Islamic schools' teachers and monks were quite intense. A common narrative that we heard from students is that they bowed before Buddhist teachers as an act of paying respect, which is equal to kissing hands of Muslim teachers.

On the other hand, the presence of non-Muslim particularly Buddhist teachers in the Islamic schools and the intensive interactions that have occurred between them and Muslim students and teachers did not easily delete the feeling of prejudice and, to some extent, feeling threatened. The vice principal of Narathiwat's Islamic school said:

I always remind my students to be very careful in making friends with Buddhists. It is good if they can influence the Buddhists, but often they are influenced. ${ }^{36}$

In Yala's Islamic school, the principal explained that there was

35 Interview with Wamdi, a teacher in Pattani's islamic school, 15 Sep 2015.

36 Interview with the Vice Principal of Narathiwat's islamic school, 5 Sep 2015. 
a desire for employing only Muslim teachers who share the belief and faiths and understand how to integrate Islam and sciences. To him, having non-Muslim teachers was complicated to manage particularly to meet their religious and cultural rights in the context where heavy Islamic cultures were imposed.

\section{E. Influential Factors}

The practices of teaching Islamic studies in the three Islamic schools in the three provinces of Southern Thailand were shaped by several factors. We identified at least three intersecting factors, namely: personal, ideological, and socio-political factors.

\section{Personal}

The personal, mostly teachers', perspectives of diversity and differences influenced the way Islamic studies subjects were taught. Most of them viewed positively the diverse religious and cultural reality as something inseparable from human life. However, with regards to religious diversity, they developed two attitudes, namely precautious and missionary. As previously indicated, teachers always remind students of religious others who might lead them astray from the Islamic religion. Yet, they encouraged students to use the differences as opportunity to spread Islam to religious others. This missionary vision was shared among teachers and students, but there was no single story found of how they conducted such missionary activities.

Personal experiences also played an important role in shaping the way teachers taught Islamic studies. Most of them were taught in a traditional manner since they just replicated what their teachers used to teach them. Generational transfer of knowledge and skills is common in educational practices, and this manifests in the three Islamic schools. However, a few teachers who were exposed to more various contexts and places such as the principal of Pattani's Islamic school displayed the picture differently. He graduated from Egypt and often travelled abroad. Our interview with him indicates that many programs of Islamic studies developed in his school were adopted from elsewhere. He introduced a topic of "Religious Festivals" in the Islamic ethics in order to teach students differences. This assures us that exposure to more open and 
Raihani, et al.

wide experiences equip individuals with more positive views towards differences. This was also evident in Yala's Islamic school in that teachers who graduated from Indonesian universities spread more positive attitudes towards diversity.

\section{Ideological}

The teaching of Islamic studies in the three Islamic schools were framed in an unshakeable ideology that Islam is the true religion and no other religions are true. This is actually the same as in other contexts such as Islamic schools and pesantren in Indonesia, ${ }^{37}$ where students are taught to believe that Islam is the only salvation. Therefore, teaching both religious and cultural diversities was developed and implemented, but limited by the framework of this ideology. In other words, interreligious and interethnic relations must be established following the principles of Islam. If a relationship in any forms contradicts Islamic teachings, it must not be continued, despite the differences in interpreting such teachings. Many informants, however, agreed that Islam does not prohibit Muslims to make relationships with religious others as long as not sacrificing the Islamic principles. Therefore, they restricted such relationships into economic and social relations only, whilst the matters of 'aqidah (faiths) and 'ibädah (worships) are not subjects to mutual relationship between Muslims and others.

\section{Socio-political}

As conveyed previously, the teaching of the Malay language as a part of Islamic studies subjects alongside the Thai language was intensified to equip students with both ethnic or native language and national language. All the students of the three Islamic schools spoke Thai as their national language, and only a few spoke the Malay language. The teaching of the Malay language had been diminished before a decade ago from the curriculum..$^{38}$ The revival of the Malay language teaching is a manifest of the socio-economic demand for the use of that language as

${ }^{37}$ Raihani, "Religion Classes in Indonesia: Translating Policy into Practice", in Crises and Opportunities: Past, Present and Future. (Adelaide: University of Adelaide, 2010), pp. 5-8.

38 Hasan Madmarn, The Pondok \& Madrasah in Patani, p. 73. 
a lingua franca particularly after the inauguration of ASEAN community in 2015. Southern Thailand serves as a proxy for the country to his neighbouring Malay communities including Malaysia and Indonesia as a large percentage of ASEAN populations speak Malay. Therefore, the three Islamic schools supported by the Thai government regulated that Malay must be used as the instructional language for Islamic subjects.

Politically, the teaching of the Islamic studies in the Islamic schools also represents a political accommodation by the Thai government of the Malay Muslim communities in the three areas of Southern Thailand. This policy acknowledges the Southern Thai Muslims' core ethnic and religious identities. This hybrid identity was seemingly played well by both parties to pursue their own political agenda. For the government, in the long run, Malay Muslims were expected to repay this government's accommodation by accepting wholeheartedly the authority of the Thai government. Yet for the Malay Muslims, this accommodation can be used as a means for consolidation for further struggle for independence. From the interviews with the central figures of the three Islamic schools, the schools have benefited from the lenient policies of the Thai government towards Malay Muslims. One of the figures argued: "the end is not the teaching of Malay as our ethnic identity nor the teaching of Islamic studies, but there is history that has to be read comprehensively in solving the problem of the Southern Thai conflict." ${ }^{39}$ It is clear that some Malay Muslims remain persistent with the struggle for self-determination or independence.

\section{F. Concluding Remaks}

The Islamic schools studied in the three provinces - Pattani, Narathiwat, and Yala - were a transformed form of the previous pondoks. They have now been incorporating saman (government) curriculum juxtaposed with the existing Islamic studies. The vision of the schools has now changed from becoming an institution for Islamic teachings to becoming one for both Islamic and saman, and in the long run, for the creation of pious as well as modern Muslim individuals. Despite this ideal curriculum orientation, the design and presentation of both curricula were

39 Interview with an informant whose name and role cannot be revealed here, 7 Sep 2015. 
Raihani, et al.

totally separated - no indication of efforts to integrate both curricula in order to adapt to such an ideal vision. This can be understood because the purpose of adopting the government curriculum was pragmatic merely to equip students with more formal education and diplomas so that they can continue to a higher level of education.

The development of Islamic studies subjects fell squarely within the concept of teaching into religion using a heavy confessional approach to the curriculum development and classroom instructions. Consequently, the presentation of other faiths and cultures, if any, was designed to fit this approach, i.e. exploring weaknesses and fallacies from a single believed-Islamic perspective, even though students were told to become tolerant individuals. In terms of classroom instruction of the Islamic subjects, teachers did a little to ensure that students' autonomy of thinking was granted, whilst every student is unique and has the right to express his/her voices. They taught Islamic dogmas and doctrines with a little opportunity to encourage critical questions from students. As previously explained, teachers' educational background was quite influential in these pedagogical practices. Having been educated in the pondoks with traditional methods of teaching, they followed suit it. Unfortunately, we did not find any information about experiences sharing or exchanges between Islamic and saman teachers nor about professional development for Islamic teachers, whilst this could be beneficial for both, even though we realise that saman pedagogy could possibly not fit perfectly Islamic pedagogy.

Above all, however, the unstable political situation in the area has clearly shaped, and in some cases obstructed, the Islamic education system. Suspicion and mistrust remain strong between both the state and Islamic education institutions. We often heard from our informants expressions of hatred and prejudice towards the state and Buddhist community for the occupation of the Malay-Muslim lands. Within this unsupportive condition, the Islamic schools demonstrated willingness to comply with the state's regulations to teach saman subjects to the students. We did not know if such compliance was sincere, but the policy of forced integration through education by the state seemed to be successful in a sense that it has opened an access to the inside of Islamic schools for oversight and scrutiny for security reasons. It seems that the game "who benefits from whom" is being played. 
Delivering Islamic Studies and Teaching Diversity

\section{BIBLIOGRAPHY}

Anthony Davis, "Thailand Confronts Separatist Violence in Its Muslim South", IHS Jane's Intelligence Review, 2004.

Banks, James A., Cultural Diversity and Education: Foundations, Curriculum, and Teaching, 5th edition, Boston: Pearson Education, 2006.

Brooks, Melanie Carol and Ekkarin Sungtong, "We still have bombings': school principals and insurgent violence in Southern Thailand", International Journal of Leadership in Education, vol. 19, no. 5, 2016, pp. 505-33 [http://dx.doi.org/10.1080/13603124.2015.1059489].

Chalk, Peter, The Malay-Muslim Insurgency in Southern Thailand -- Understanding the Conflict's Evolving Dynamic, Occasional Papers, no. 5, Santa Monica, CA: RAND Corporation, 2008.

Charlene Tan, "Christian Education Without the Problem of Indoctrination", Quodlibet Journal, vol. 5, no. 4, 2003.

Corson, David, Changing Education for Diversity, Buckingham: Open University Press, 1998.

DeLong-Bas, Natana J., Wabhabi Islam: From Revival and Reform to Global Jihad, Oxford: Oxford University Press, 2004, http://site.ebrary. com/id/10266510.

Diptendu, Sarkar, "Religious Minority, Education and Separatism in South Thailand", Thailand in the World., Sydney: University of Sydney, 2014.

Don Pathan and Joseph Chinyong Liow, Confronting Ghosts: Thailand's Shapeless Southern Insurgency, no. 30, Lowy Institute for International Policy, 2010.

Grimmitt, Michael, Religious Education and Human Development: The Relationship between Studying Religions and Personal, Social and Moral Education, Great Wakering, Essex: McCrimmon, 1987.

Halstead, J. Mark, "An Islamic Concept of Education", Comparative Education, vol. 40, no. 4, 2004, pp. 517-29.

Hasan Madmarn, The Pondok \& Madrasah in Patani, Selangor: UKM Press, 1999.

Kalve, Peter, "Some Aspects of the Work of Michael Grimmitt", British Journal of Religious Education, vol. 18, no. 3, 1996, pp. 181-90 [http:// 
Raihani, et al.

dx.doi.org/10.1080/0141620960180306].

Liow, Joseph Chinyong, Muslim Resistance in Southern Thailand and Southern Philippines: Religion, Ideology, and Politics, Washington, D.C.: East-West Center, 2006.

----, "International Jihad and Muslim Radicalism in Thailand?: Toward an Alternative Interpretation", Asia Policy, vol. 2, no. 1, 2006, pp. 89-108 [http://dx.doi.org/10.1353/asp.2006.0004].

----, Islam, Education, and Reform in Southern Thailand: Tradition \& Transformation, Singapore: Institute of Southeast Asian Studies, 2009.

Lukens-Bull, Ronald A., "Two Sides of the Same Coin: Modernity and Tradition in Islamic Education in Indonesia", Anthropology \& Education Quarterly, vol. 32, no. 3, 2001, pp. 350-72.

Miles, Matthew B. and A.M. Huberman, Qualitative Data Analysis: an Expanded Sourcebook, Thousand Oaks: Sage Publications, 1994.

Noorhaidi Hasan, "The Salafi Madrasas in Indonesia”, in The Madrasa in Asia: Political Activism and Transnational Linkages, ed. by Farish A. Noor, Yoginder Sikand, and Martin van Bruinessen, Amsterdam: Amsterdam Univ. Press, 2008.

Raihani, "Religion Classes in Indonesia: Translating Policy into Practice", Crises and Opportunities: Past, Present and Future., Adelaide: University of Adelaide, 2010.

Robert Jackson, "Intercultural Education, Religious Plurality and Teaching for Tolerance", in Intercultural Education and Religious Plurality, ed. by Robert Jackson and Ursula McKenna, Oslo: The Oslo Coalition on Freedom of Religion or Belief, 2005.

----, "Tolerance in Religious and Citizenship Education: Interpretive and Dialogical Approaches", presented at the Teaching for Tolerance in the Indonesian Context, Makassar, 2007.

Saleemad, Khanittha, Suwattana Eamoraphan, and Watana Vinitwatanakhun, "Development of a Leadership Model for Islamic School Leaders in Thailand", Scholar, vol. 4, no. 2, 2012.

Taylor, Tracy and Kristine Toohey, "Negotiating Cultural Diversity for Women in Sport: From Assimilation to Multiculturalism", Race Ethnicity and Education, vol. 1, no. 1, 2006, pp. 75-90 [http://dx.doi. 
Delivering Islamic Studies and Teaching Diversity

org/10.1080/1361332980010106].

Von Feigenblatt, Otto, "The Muslim Malay Community in Southern Thailand: A 'Small People' Facing Existential Uncertainty”, Ritsumeikan Journal of Asia Pacific Studies, vol. 27, 2010. 
Raihani, et al. 